\title{
КООПЕРАТИВНОЕ ДВИЖЕНИЕ В ЗАПАДНОМ ЗАБАЙКАЛЬЕ В НАЧАЛЕ ХХ ВЕКА
}

Кооперативное движение, распространившееся в России, в начале XX в. охватило Западное Забайкалье в форме потребительских и кредитных обществ. Его возникновение было связано, во-первых, с необходимостью обеспечения товарами членов общества, во-вторых, с возможностью участия в нем всех сословий. Кооперативное движение занималось торговлей, удовлетворяя необходимые потребности не только своих членов, но и всего населения, а также занималось кредитованием зажиточных крестьян. Объединение потребительских обществ Западного Забайкалья в одно, получившее название «Прибайкалсоюз», усилило конкурентоспособность, увеличило возможности оптовой торговли, транспортировки грузов, аренды помещений. В годы первой мировой войны в связи с переходом промышленности на выполнение военных заказов и возникновением дефицита, потребитель- 
ские общества кроме торговых операций стали заниматься промышленным производством. Они развивали только финансово доступные для обществ производства.

Ключевые слова: кооперация, потребительские общества, Западное Забайкалье, торговля, промышленность.

T.E. SANZHIEVA

\section{COOPERATIVE MOVEMENT IN TRANSBAIKALIA IN THE EARLY XX CENTURY}

The cooperative movement spread in Russia in the early XX century embraced Transbaikalia in the form of consumer and credit societies. Its emergence was connected, firstly, with the need to provide goods to members of society, and secondly, with the possibility of participation of all classes. The cooperative movement was engaged in trade, meeting the necessary needs not only of its members, but also of the entire population, and also engaged in lending to wealthy peasants. The Union of consumer societies of the Western Transbaikalia in one, dubbed "Pribaikalsouz", strengthened competitiveness, increased opportunities in wholesale trade, transportation of goods, rental of premises. During the first world war, in connection with the transition of industry to fulfill military orders and the emergence of a deficit, consumer societies in addition to trade operations began to engage in industrial production. They developed only financially accessible for production companies.

Keywords: cooperation, consumer societies, Transbaikalia, trade, industry.

Большую роль в снабжении товарами населения сыграло кооперативное движение. Одним из самых распространенных стало создание потребительской кооперации. Ее цель заключалась в организации снабжения своих членов товарами высокого качества за умеренную плату. Правительство к организации потребительских обществ относилось сдержанно. Открытие общества разрешалось при санкции министерства внутренних дел и финансов. На получение разрешения на организацию потребительского общества требовалось не менее года. Чем сложнее становилась ситуация на потребительском рынке, тем больше возникало обществ.

В Сибири первые потребительские общества стали появляться в 1860-е гг. В 1911 г. в Сибири функционировало 131 общество потребителей, в Забайкалье - 6 кооперативов [1, с. 50]. Среди населения Западного Забайкалья общества потребителей кооперативного типа стали возникать с 1911 г. в сельской местности. Первыми обществами потребителей были Каралаунское (Баргузинский уезд) и Корсаковское (Кударо-Бурятская волость, Селенгинский уезд). Несколько позднее воз- 
никли общества потребителей в Батурине, Оймуре, Кударе, Кабанске, Куналее и Харашибире [8, с. 38]. Причиной возникновения было желание пайщиков, объединив свои капиталы, обеспечить себя необходимыми товарами (ткани, мыло, керосин, спички и т.д.) по низким ценам. Для этого они производили оптовые закупки непосредственно у производителей в обход посредников. К 1914 г. в Западном Забайкалье сложилось 10 обществ потребителей. В городах России, в том числе и в г. Верхнеудинске стали открываться потребительские общества «Экономия». Верхнеудинское городское потребительское общество «Экономия» было самым крупным в Забайкалье. Оно было создано по инициативе профрсоюза общественной организации «Общества вспоможения приказчиков» (март 1913 г.). С сентября 1913 г. потребительское общество приступило к осуществлению торговой деятельности. Помещение для торговой лавки оно арендовало у торгового дома «Федоров и Гершевич» [7, с. 96]. Вторая лавка была открыта в сентябре 1914 г. в Нагорной части города (ныне Батарейка) и в июле 1916 г. третья лавка - за Удой. Сначала торговали бакалейной продукцией, затем в торговый оборот ввели галантерейные и другие товары [7, с. 97].

Так же стали возникать кредитные товарищества. В 1909 г. открываются - Омулевское, Кабанское, Корсаково-Дуланское и Степно-Дворецкое товарищества. В 1912 г. насчитывалось 19 кредитных товариществ с общим капиталом в 205090 р., объединивших 6060 членов, а в 1913 г. их уже стало 44 с общим капиталом в 400247 р. и 13084 членами [1, с. 55].

Кредитные товарищества образовались в результате сложения свободных капиталов средней и мелкой буржуазии, преимущественно сельских районов. Эти товарищества в основном занимались только субсидированием зажиточных крестьян.

Накануне войны разобщенные потребительские общества стали объединяться. Крупное объединение обладало рядом преимуществ по сравнению с мелкими кооперативами. Оно было менее уязвимо со стороны конкурентов, проще и быстрее решало назревшие вопросы, связанные с оптовыми закупками, реализацией, транспортировкой товаров и т.д. Первые союзы потребительской кооперации в Сибири возникли в 1912 г., через два года их было четыре [1, с. 53].

В январе 1914 г. в г. Верхнеудинске по инициативе потребительского общества «Экономия» на съезде кооператоров Западного Забайкалья, представленном Верхнеудинским, Кударинским, Харашибирским, Кабанским, Оймурским потребительскими обществами, а также Батуринским кредитным товариществом, был создан Прибайкальский торгово-промышленное товарищество кооперативов («Прибайкалсоюз»). Его основной задачей стало «снабжение необходимыми товарами кооперативов экономически тяготеющих к Верхнеудинскому рынку, ведение 
посреднических операций между ними, приобретение и сбыт продуктов сельского хозяйства, устройство складов, открытие отделений, торговых агентур, контор, а также приобретение фабрик, заводов и обрабатывающих предприятий в свою собственность, аренда и покупка движимого и недвижимого имущества, заключение отношений с кредитными, страховыми и другими фринансовыми учреждениями» [2, л. 102]. «Прибайкальское торгово-промышленное товарищество кооперативов состоит из кооперативных учреждений и учреждений на паях. Пай обязательный равняется ста рублям, при этом число паев каждого товарища не ограничено», - записано в Договоре о появлении Товарищества под названием «Прибайкальское торгово-промышленное товарищество кооперативов» [3, л. 1]. С его созданием стало быстро расти количество обществ потребителей. Если ко времени образования товарищества было 10 обществ, то к концу 1916 г. - уже 109, а к концу 1917 г. - 206.

«Прибайкалсоюз» открыл свои операционные действия в марте 1914 г. в составе 9 кооперативных обществ с суммой капитала 509 р. В январе 1915 г. в него вступили 17 потребительских обществ и 3 кредитных товарищества. Капитал «Прибайкалсоюза» составил 2770 р. [6, с. 129]. Городские общества потребителей «Экономия» следом за Верхнеудинском возникли в Троицкосавске, Мысовске, Баргузине и Петровск-Заводске [8, с. 38-39]. Непосредственными причинами возникновения обществ были дефицит и дороговизна некоторых видов товаров. Объединение в общество позволяло суммировать свои капиталы и совершать закупки товара оптом у производителей. Тем самым добивались снижения цены на эти товары для собственного потребления и получали его бесперебойно, хоть и не всегда в достаточной мере.

В годы войны широко развернулось кооперативное движение. В жестокой конкурентной борьбе против частных торговцев потребительские кооперативы выходили победителями, как представители более крупного объединенного капитала. Спекуляция крупных торговых домов и острый дефицит промышленных товаров вызвали массовый приток крестьян в потребительскую кооперацию. Заявления крестьян Сибири с просьбой открыть кооператив стал поступать широким потоком с 1915 г. В результате конкуренции со стороны кооперативов, многие купцы ликвидировали свои дела и вкладывали капиталы в производство на войну [5, с. 443].

В условиях товарного голода в годы войны благодаря усилиям потребительских кооперативных обществ рынок Западного Забайкалья насыщался товарами. Централизованными закупками занимался «Прибайкалсоюз», активно сотрудничая с потребительским общество «Экономия» и с органами местного самоуправления города.

Верхнеудинское потребительское общество «Экономия» в годы войны прилагало все усилия для удержания цен на продовольствие и то- 
вары первой необходимости, однако ограниченность средств общества не сокращала эффективность его деятельности. При магазинах Верхнеудинского общества потребителей «Экономия» (на Базарной площади в доме насл. Фролова и на углу Кяхтинской и Железнолдорожных улиц в д. Белова) был открыт городской склад продуктов первой необходимости, их продажа производилась по заготовительной стоимости с начислением не более 5 \% для возмещения обществу «Экономия» расходов по найму служащих, помещений, усушки, утряски продуктов. Помещение под склады Городская управа выделила бесплатно [3, л. 25].

Проблема с обеспечением продуктами питания и товарами первой необходимости населения г. Верхнеудинска обострялась. 25 июня 1915 г. на экстренном заседании Верхнеудинской городской думы Городской голова К.И. Легков выступил с предложением просить Читинское отделение Государственного банка о выделении ссуды в размере 20 тыс. р. на приобретение продовольствия и товаров первой необходимости для населения г.Верхнеудинска. Представитель Верхнеудинского потребительского общества «Экономия» предложил ходатайствовать перед Продовольственным комитетом о выдаче городу беспроцентной ссуды на продовольствие в размере 100 тыс. р., поскольку для снижения дороговизны 20 тыс. р. мало [3, л. 11].

По инициативе «Экономии» был создан Продовольственный комитет, в состав которого вошли три представителя от Верхнеудинской управы (И.Г. Вторушин, Г.А. Астраханцев, В.А. Воробьев) и три от кооперативов (А.Н. Кубасов, А.А. Нечунаев, Г.И. Камынин) [3, л. 10]. Заготовку продуктов и товаров стало осуществлять потребительское общество «Экономия» под надзором Продовольственного комитета через Прибайкалсоюз. Так, в 1916 г. было заготовлено товаров на сумму свыше 130 тыс. р. [7, с. 130].

За годы войны Прибайкальское торгово-промышленное товарищество кооперативов стало крупным учреждением кооперативной торговли, занимаясь торгово-посреднической деятельностью, оно проводило финансовые операции, умело работало с банками. В 1917 г. оно объединяло 195 обществ потребителей. В течение одного года (1917) оборот товарищества вырос более чем в 3,5 раза. Оно имело в кассе более 10 млн р., товаров на сумму свыше 14,5 млн р. [6, с. 39].

В годы войны причиной роста потребительских обществ стала ситуация, когда достать продукты и одежду было невозможно, если человек не состоял в кооперативе. Это заставляло людей организовываться для совместной деятельности. В первый военный год наблюдался значительный рост кооперативов. Но многие из них, не обладая достаточными средствами, закрывались впоследствии. В 1919 г. в Восточной Сибири было 1735 обществ, в Западной Сибири - 3 082, на Дальнем Востоке - 676 обществ [1, с. 52]. 
В годы Первой мировой войны объединение кооперативов шло и на уровне страны. Так, в 1916 г. на съезде потребительской кооперации, состоявшемся при Новониколаевском отделении Московского Народного Банка, была создана товарная комиссия по закупкам и сбыту под общим названием Закупсбыт. Торговая деятельность Закупсбыта была связана с реализацией и заготовкой хлеба, пушнины, мясо-молочных продуктов, меда, табака. В 1916 году торговый оборот в золотом выражении представлял 514326 р., в 1917 г. - 1626619 р., в 1918 г. 8034581 р. [1, с. 63]. В 1918 г. в нее входили 34 кооперативных союза из 40 существовавших в Сибири, в том числе Прибайкалсоюз. Закупсбыт занимался не только снабжением местного населения, но и организовывал поставку в армию мяса, мала, зерна, фуража. В годы войны нелегко было скупать зерно у крестьян. Они часто не желали продавать хлеб для армии по низким ценам, в городах хлеб можно было реализовать по спекулятивным ценам. Кооператорам приходилось прилагать немало усилий для приобретения и поставки продуктов армии.

В 1918 г. в состав Прибайкалсоюза входило 226 кооперативов, 50000 членов [1, с. 66].

В условиях войны деньги сильно обесценивались, инфляция нарастала, на свои деньги крестьяне не могли купить промышленные товары.

Упадок промышленности и торговли в масштабах страны породил необходимость создания ряда производств местными силами. Кооперация развивала только те производства, которые не требовали больших средств. «Прибайкальское торгово-промышленное товарищество кооперативов» (Прибайкалсоюз) скупал у частных предпринимателей мелкие промышленные предприятия. В 1916 г., например, он купил в с. Новая Курба небольшой кожевенный завод производительностью около 500 кож в месяц, имевший пять дубильных и один потаржной чаны, четыре зольник, конную дуборезку. Завод выделывал сыромятную, сапожную и чирочную кожи, а также проводил в небольшом объеме дубление. При заводе была мастерская для шитья ичиг, изготавливающего около 120 пар в месяц. Завод использовал сырье местного происхождения, химические препараты доставлялись из России и Китая. Завод находился в 35 верстах от железнодорожной станции Онохой [3, л. 1]. В том же году в Верхнеудинске на батарейной площади товариществом были приобретены паровая мукомольная мельница и лесопильный завод за 190 тыс. p. $[4$, л. 10]. Лесопильно-мукомольный завод имел паровой котел и машину, два мельничных 7/4 постава один Траппа, другой Жуковского, лесопильную раму и циркулярную поперечную пилу, паровую сушилку, вальцы для дробления зерна, сбойку для очистки зерна, крупорушку и четыре сортировки. Производительность мельницы составляла до 30 тыс. пудов в месяц, лесопильной рамы и поперечной пилы - более 800 деревьев в месяц. Зерно поступало из деревень округи, а лес сплавлялся с верхо- 
вьев р. Уды. Завод находился на окраине г. Верхнеудинска в двух верстах от железнодорожной станции [3, л. 1]. В 1915 г. товарищество открыло в Верхнеудинске сушечно-пряничную мастерскую [3, л. 10].

Прибайкалсоюз взял в аренду у правительства сроком на 30 лет маслобойный, чугунно-литейный и кирпичные заводы. В Троицкосавске и Верхнеудинске он владел типографриями [7, с. 130]. В фреврале 1918 г. Прибайкалсоюз пустил в ход кожевенный и овчинный заводы в Петровском Заводе. Кожевенный завод, производивший 12 тыс. кож в год, был оборудован одним дубильным барабаном и дуботолкой, работавших на паровом двигателе. Овчинный завод выделывал 36 тыс. овчин в год. Сушка овчины проводилась паровым способом. При овчинном заводе была мастерская по пошиву шуб, производительностью 7200 штук в год [3, л. 2].

Промышленные предприятия Прибайкальского товарищества кооперативов выпускали предметы широкого потребления, как для сельского, так и для городского населения. Наиболее ходовыми из них были полушубки, шапки, рукавицы, мыло, выделанная кожа и обувь (ичиги) [3, л. 40].

Кооперативное движение Западного Забайкалья в начале XX в. развивалось как потребительская кооперация. Организованное, как движение «снизу», оно восполнило рынок необходимым товаром. Поскольку кооперативные общества состояли из потребителей, то они могли быстро реагировать на спрос. Потребительские общества, особенно «Экономия», «Прибайкалсоюз» позволили активным гражданам участвовать в торговле и промышленном производстве, обеспечивать своих членов товарами по низкой цене, а также продукцией собственного производства. В Западном Забайкалье из-за малочисленности работников промышленного производства рабочие кооперативы не создавались. Членами потребительских обществ были сельские жители, зажиточные и средние крестьяне. Кредитная кооперация была менее популярна изза узкой финансовой базы. Если до войны потребительские общества создавались для торговли, то в годы войны кооперация стала заниматься производственно-сбытовыми операциями.

Кооперативное движение сократило дефицит товаров, тем самым облегчило жизнь населения Западного Забайкалья, а также приобщило к управлению в торговле и производстве.

\section{Список использованной литературы и источников}

1. Алексеева В. К. Кооперативное движение в Сибири (конец XIX - начало XX века) / В. К. Алексеева. - Новосибирск : Изд-во НГУ, 1993. - 119 с.

2. Государственный архив Республики Бурятия (ГАРБ). - Ф. 10 (Верхнеудинская городская управа). - Оп. 1. - Д. 1153.

3. ГАРБ. - Ф. 10. - Оп. 1. - Д. 2829. 
4. ГАРБ. - Ф. Р-228 (Прибайкальское торгово-промышленное товарищество кооперативов (Буркоопсоюз)). - Оп. 4. - Д. 17.

5. История Сибири.- Л. : Наука. Ленингр. отд-ние, 1968. - Т. 3. - 535 с.

6. Ломакина И. Б. Возникновение и развитие «Прибайкальского торгово-промышленного товарищества кооперативов» (1914-1917 гг.) / И. Б. Ломакина // Архивы Бурятии и историческая наука : материалы науч.-практ. конф., посв. 75-летию архивной службы Республики Бурятия. - Улан-Удэ : Ком. по делам архивов РБ, 1998. - С. 128-132.

7. Ломакина И. Б. Кооперативное движение в Забайкалье 1910 - февраль 1917 гг. : дис. ... канд. ист. наук / И. Б. Ломакина. - Улан-Удэ, 2000. — 224 с.

8. Хаптаев П. Т. Октябрьская социалистическая революция и гражданская война в Бурятии / П. Т. Хаптаев. -Улан-Удэ : Бурят. кн. изд-во, 1964. — 336 с.

\section{Информация об авторе}

Санжиева Татьяна Ефремовна - доктор исторических наук, профессор, кафедра истории Бурятии, Бурятский государственный университет, 670000, г. Улан-Удэ, ул. Смолина, 24a; e-mail: sanj_te@mail.ru

\section{Author}

Tatiana E. Sanzhieva - Doctor of History, Professor, Chair of Buryat History, Buryat State University, 24a Smolin St., 670000, Ulan-Ude, Russia; e-mail: sanj_te@mail.ru 